\title{
A Survey of Bacterial Respiratory Pathogens in Native and Introduced Mountain Goats (Oreamnos americanus)
}

\begin{abstract}
Authors: Blake Lowrey, Carson J. Butler, William H. Edwards, Mary E. Wood, Sarah R. Dewey, Gary L. Fralick, Jessica Jennings-Gaines, Halcyon Killion, Douglas E. McWhirter, Hollie M. Miyasaki, Shawn T. Stewart, Kevin S. White, Patrick J. White, and Robert A. Garrott
\end{abstract}

This is a postprint of an article that originally appeared in Journal of Wildlife Diseases on June 2018. The final version can be found at https://dx.doi.org/10.7589/2018-02-025.

Lowrey, Blake, Carson J. Butler, William H. Edwards, Mary E. Wood, Sarah R. Dewey, Gary L. Fralick, Jessica Jennings-Gaines, Halcyon Killion, Douglas E. McWhirter, Hollie M. Miyasaki, Shawn T. Stewart, Kevin S. White, Patrick J. White, and Robert A. Garrott. "A Survey of Bacterial Respiratory Pathogens in Native and Introduced Mountain Goats (Oreamnos americanus)." Journal of Wildlife Diseases (June 2018). DOI:10.7589/2018-02-025. 


\title{
A Survey of Bacterial Respiratory Pathogens in Native and Introduced Mountain Goats (Oreamnos americanus)
}

\begin{abstract}
Blake Lowrey, ${ }^{1,10}$ Carson J. Butler, ${ }^{2}$ William H. Edwards, ${ }^{3}$ Mary E. Wood, ${ }^{3}$ Sarah R. Dewey, ${ }^{2}$ Gary L. Fralick, ${ }^{4}$ Jessica Jennings-Gaines, ${ }^{3}$ Halcyon Killion, ${ }^{3}$ Douglas E. McWhirter, ${ }^{5}$ Hollie M. Miyasaki, ${ }^{6}$ Shawn T. Stewart, ${ }^{7}$ Kevin S. White, ${ }^{8}$ Patrick J. White, ${ }^{9}$ and Robert A. Garrott ${ }^{1}{ }^{1}$ Fish and Wildlife Ecology and Management Program, Ecology Department, Montana State University, 310 Lewis Hall, Bozeman, Montana 59717, USA; ${ }^{2}$ National Park Service, Grand Teton National Park, PO Box 170, Moose, Wyoming 83012, USA; ${ }^{3}$ Wyoming Game and Fish Department Wildlife Health Laboratory, 1174 Snowy Range Road, Laramie, Wyoming 82070, USA; ${ }^{4}$ Wyoming Game and Fish Department, PO Box 1022, Thayne, Wyoming 83127, USA; ${ }^{5}$ Wyoming Game and Fish Department, 2820 State Highway 120, Cody, Wyoming 82414, USA; ${ }^{6}$ Idaho Department of Fish and Game, 4279 Commerce Circle, Idaho Falls, Idaho 83401, USA; ${ }^{7}$ Montana Fish Wildlife and Parks, PO Box 581, Red Lodge, Montana 59068, USA; ${ }^{8}$ Alaska Department of Fish and Game, Division of Wildlife Conservation, PO Box 240020, Douglas, Alaska 99824, USA; ${ }^{9}$ National Park Service, Yellowstone National Park, PO Box 168, Mammoth, Wyoming 82190, USA; ${ }^{10}$ Corresponding author (email: blakelowrey@montana.edu)
\end{abstract}

ABSTRACT: In contrast to broad range expansion through translocations, many mountain goat (Oreamnos americanus) populations have shown signs of decline. Recent documentation of pneumonia in mountain goats highlights their susceptibility to bacterial pathogens typically associated with bighorn sheep (Ovis canadensis) epizootics. Respiratory pathogen communities of mountain goats are poorly characterized yet have important implications for management and conservation of both species. We characterized resident pathogen communities across a range of mountain goat populations as an initial step to inform management efforts. Between 2010 and 2017, we sampled 98 individuals within three regions of the Greater Yellowstone Area (GYA), with a smaller sampling effort in southeast Alaska, US. Within the GYA, we detected Mycoplasma ovipneumoniae in two regions and we found at least two Pasteurellaceae species in animals from all regions. Mannheimia haemolytica was the only pathogen that we detected in southeast Alaska. Given the difficult sampling conditions, limited sample size, and imperfect detection, our failure to detect specific pathogens should be interpreted with caution. Nonetheless, respiratory pathogens within the GYA may be an important, yet underappreciated, cause of mountain goat mortality. Moreover, because of the strong niche overlap of bighorn sheep and mountain goats, interspecific transmission is an important concern for managers restoring or introducing mountain ungulates within sympatric ranges.

Key words: Bighorn sheep, disease, mountain goat, Mycoplasma ovipneumoniae, Oreamnos americanus, Pasteurellaceae, pneumonia.

At the time of European settlement of North America, mountain goats (Oreamnos americanus) were distributed from the main- land mountain ranges of southern Alaska, throughout the western Canadian Provinces and Territories, and into the northwestern US including Washington, Oregon, and western Idaho and Montana (Côté and Festa-Bianchet 2003). While mountain goats did not experience the level of overexploitation and reduction typical of other North American ungulates, wildlife management agencies included mountain goats in translocation programs during the early- to mid-1900s and expanded their distribution beyond known historical ranges (Côté and Festa-Bianchet 2003). Translocation efforts are considered a success, with introduced populations now established throughout the western US and Canada (Flesch et al. 2016). Nonetheless, in contrast to general range expansion through translocation, many populations show signs of decline. For example, today native populations in Montana (outside of Glacier National Park) are a third to a quarter of their estimated abundances in the 1940s (Smith and DeCesare 2017). Moreover, mountain goat abundance in British Columbia, Canada, and Washington state declined by at least half from the 1950s and 60s to the early 2000s (Mountain Goat Management Team 2010; Rice and Gay 2010).

The difficulty in studying mountain goats presents a number of challenges in documenting cause-specific declines, which can include anthropogenic causes or predation (Côté and Festa-Bianchet 2003). While driv- 
ing factors are regionally specific, recent documentation of pneumonia in adult and kid mountain goats in Nevada (Wolff et al. 2014; Anderson et al. 2016) highlights the susceptibility of mountain goats to pneumonia pathogens typically associated with bighorn sheep (Ovis canadensis) epizootics (Blanchong et al. 2018; Cassirer et al. 2018). Given the broad distribution of respiratory pathogens in bighorn sheep (Butler et al. 2017), susceptibility of mountain goats to epizootics may be a more-widespread cause for concern. Moreover, where mountain goats are sympatric with bighorn sheep there is strong niche overlap (Lowrey et al. 2018) and potential for interspecific disease transmission (Wolff et al. 2016; Blanchong et al. 2018). Resident pathogen communities of mountain goats are poorly characterized yet have important implications for management and conservation of both mountain ungulate species. We evaluated mountain goat respiratory samples collected through multiple monitoring efforts in Montana, Wyoming, Idaho, and Alaska to regionally characterize the resident pathogen community across a diverse range of mountain goat populations as an initial step to inform management efforts.

Sampling efforts were conducted within three regions of the Greater Yellowstone Area (GYA), with a smaller sampling effort in southeast Alaska (Fig. 1). Mountain goats are considered nonnative in the GYA and grew from 170 individuals introduced in the mid 1900s to roughly 1,650 individuals in 2016 (Flesch et al. 2016). Sampling efforts in the GYA targeted three regions: the northeast GYA, including portions of Yellowstone National Park, Grand Teton National Park (GTNP), and the southwest GYA, including the Snake River Range of Wyoming and Idaho (Fig. 1). Mountain goats are sympatric with bighorn sheep in the northern GYA and GTNP but are considered allopatric in the southwest GYA. Historically, all populations in the GYA were broadly sympatric with domestic livestock. We provided a comparison with native populations that have never shared ranges with domestic livestock by sampling four populations in southeast Alaska (Fig. 1).
While the southwest GYA is the presumed source of mountain goats colonizing GTNP (Lowrey et al. 2017), there is no other suspected connectivity between the four regions.

We captured mountain goats via ground darting, helicopter net-gunning, or helicopter darting between 2010 and 2017. All captures were conducted in accordance with Montana State University Institutional Animal Care and Use Committee (2011-17, 2014-32) and agency permits. Following extensive studies in bighorn sheep (Besser et al. 2013; Butler et al. 2017), we focused on the presence of Pasteurellaceae organisms (specifically leukotoxigenic and beta-hemolytic Bibersteinia trehalosi, Mannheimia haemolytica, and Mannheimia spp. as well as Pasteurella multocida) from tonsil swabs and Mycoplasma ovipneumoniae from nasal swabs. Sampling protocols varied between regions, but generally adhered to Butler et al. (2017). The protocols varied with respect to the transport media for swabs, the type of diagnostic test to identify pathogens, and the diagnostic laboratory that conducted the analyses. All samples were collected using sterile, polyester-tipped applicators. Transport media included Port-A$\mathrm{Cul}^{\mathrm{TM}}$ tubes (BD, Sparks, Maryland, USA), tryptic soy broth with $15 \%$ glycerol (TSB; Hardy Diagnostics, Santa Maria, California, USA) vials, and immediate inoculation of Columbia blood agar culture plates (Hardy Diagnostics). The inoculated TSB vials were frozen as soon as possible after each capture and later shipped overnight on dry ice to prevent freeze-thaw cycles. We assessed the presence of pathogens using a combination of PCR and culture techniques. We delivered samples to the Washington Animal Disease Diagnostic Laboratory or the Wyoming Game and Fish Department Wildlife Health Laboratory for detection and identification of respiratory pathogens. We did not account for detection probability (Butler et al. 2017) and present our results as a minimum resident pathogen community within each region.

We sampled a total of 98 individuals across the four study regions. Due to local logistics and funding availability, there was notable 

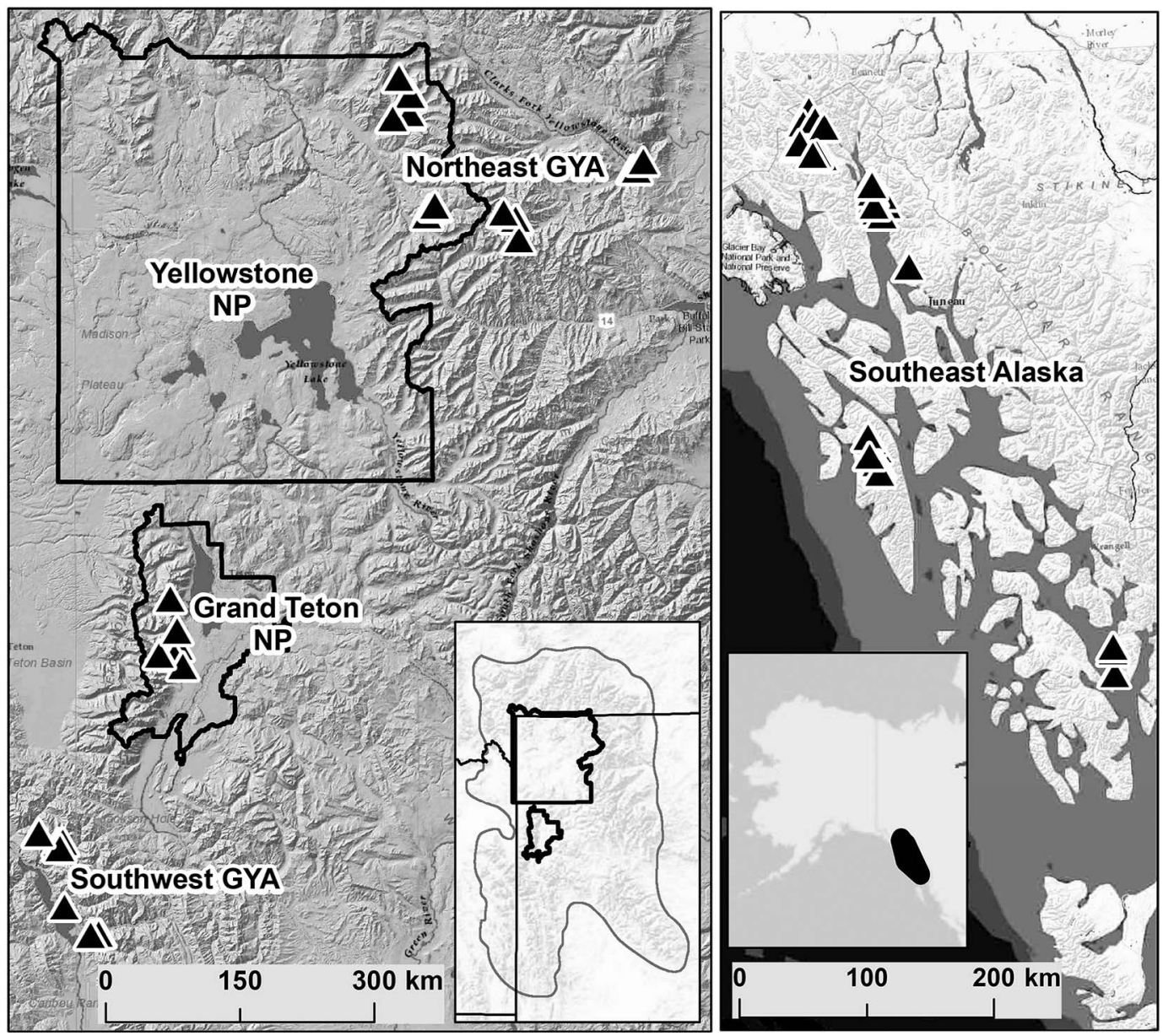

Figure 1. Greater Yellowstone Area (GYA; left) and southeast Alaska (right) study regions for a survey of bacterial respiratory pathogens in mountain goats (Oreamnos americanus). Triangles represent mountain goat capture locations 2010-17. With the exception of Grand Teton National Park (NP) and the southwest GYA, each study region was an isolated aggregate of individuals. While there were varying degrees of connectivity within each region, meaningful population-level inferences were not possible with the spatial and temporal resolution of our sampling efforts.

variation in the number of yearly samples collected (mean $=9, \mathrm{SD}=5.34$, range $=1-20$ ). The PCR was the only diagnostic test used in all laboratory, year, and study area combinations for the detection of $M$. ovipneumoniae and had positive detections in the northeast and southwest GYA (Table 1). Mycoplasma ovipneumoniae was not detected in GTNP or southeast Alaska. With the exception of the southwest GYA, serology tests strongly agreed with the PCR results. The cause of discrepancy in the southwest GYA in 2013 was unknown, but could have been related to sample size, sample timing in relation to nasal shedding, or the PCR assay which had not been validated for mountain goats.

We detected B. trehalosi and Mannheimia spp. in all regions within the GYA. Mycoplasma haemolytica was detected in the northeast and southwest regions but not in GTNP. The southwest GYA was the only region where we detected P. multocida (Table 2). In contrast to the GYA, M. haemolytica was the only Pasteurellaceae species detected in southeast Alaska (Table 2). Because differentiating isolates or leukotoxins of M. haemolytica with 
TABle 1. Diagnostic summaries for Mycoplasma ovipneumoniae in samples from a survey of bacterial respiratory pathogens from mountain goat (Oreamnos americanus) populations in the Greater Yellowstone Area (GYA) and southeast Alaska. The sample size for each protocol $(n)$, as well as detected $(+)$ and not detected (-) results, are shown for PCR and serology diagnostic tests.

\begin{tabular}{|c|c|c|c|c|c|c|c|c|c|c|}
\hline \multirow[b]{3}{*}{ Location $^{a}$} & \multirow[b]{3}{*}{ Year } & \multirow{3}{*}{$\begin{array}{c}\text { No. of } \\
\text { individuals }\end{array}$} & \multirow{3}{*}{$\begin{array}{l}\text { Transport } \\
\text { mediumb }^{b}\end{array}$} & \multirow[b]{3}{*}{ Laboratory $^{\mathrm{c}}$} & \multicolumn{6}{|c|}{ Mycoplasma ovipneumoniae ${ }^{\mathrm{d}}$} \\
\hline & & & & & \multicolumn{3}{|c|}{ PCR } & \multicolumn{3}{|c|}{ Serology } \\
\hline & & & & & $n$ & + & - & $n$ & + & - \\
\hline \multirow[t]{4}{*}{ NEGYA } & 2013 & 14 & TSB & WADDL & 14 & 3 & 10 & - & - & - \\
\hline & & & $\mathrm{PC}$ & WGF & 13 & 1 & 12 & - & - & - \\
\hline & 2014 & 7 & TSB & WADDL & 7 & 1 & 5 & - & - & - \\
\hline & & & Serum & WADDL & - & - & - & 7 & 2 & 4 \\
\hline \multirow[t]{6}{*}{ SWGYA } & 2013 & 13 & TSB & WADDL & 13 & 0 & 13 & - & - & - \\
\hline & & & Serum & WADDL & - & - & - & 7 & 6 & 1 \\
\hline & & & $\mathrm{PC}$ & WGF & 5 & 0 & 5 & - & - & - \\
\hline & 2014 & 9 & $\mathrm{PC}$ & WGF & 9 & 9 & 0 & - & - & - \\
\hline & 2015 & 4 & $\mathrm{PC}$ & WGF & 4 & 2 & 2 & - & - & - \\
\hline & 2017 & 4 & $\mathrm{PC}$ & WGF & 4 & 2 & 1 & - & - & - \\
\hline \multirow[t]{6}{*}{ GTNP } & 2014 & 5 & PC & WGF & 5 & 0 & 5 & - & - & - \\
\hline & & & Serum & WGF & - & - & - & 5 & 0 & 5 \\
\hline & 2015 & 4 & PC & WGF & 4 & 0 & 4 & - & - & - \\
\hline & & & Serum & WGF & - & - & - & 4 & 0 & 4 \\
\hline & 2017 & 5 & $\mathrm{PC}$ & WGF & 5 & 0 & 5 & - & - & - \\
\hline & & & Serum & WGF & - & - & - & 4 & 0 & 4 \\
\hline \multirow[t]{3}{*}{ SEAK } & 2010 & 19 & $\mathrm{PC}$ & WADDL & 19 & 0 & 19 & - & - & - \\
\hline & 2014 & 14 & TSB & WADDL & 14 & 0 & 14 & - & - & - \\
\hline & & & Serum & WADDL & - & - & - & 16 & 0 & 16 \\
\hline
\end{tabular}

${ }^{a}$ NEGYA $=$ northeast GYA; SWGYA $=$ southwest GYA; GTNP $=$ Grand Teton National Park; SEAK = southeast Alaska.

${ }^{\mathrm{b}}$ TSB $=$ tryptic soy broth with $15 \%$ glycerol; PC $=$ Port-A-Cul.

${ }^{\mathrm{c}}$ WADDL $=$ Washington Animal Disease Diagnostic Laboratory; WGF $=$ Wyoming Game and Fish Department Wildlife Health Laboratory.

d $-=$ no test was performed.

Mannheimia glucosida is currently not possible, an unknown number of $M$. glucosida detections may have been misclassified as $M$. haemolytica. Lastly, there were no observed mountain goat die-offs in any region over the sampling period.

There was notable variation in pathogen detection within and among years (Tables 1, 2 ), which we attributed to low detection probability (Butler et al. 2017) and small annual sample sizes. Careful measures were taken to handle all samples according to protocols that optimized pathogen recovery and survival; however, mountain goats present challenging sampling conditions in rugged terrain at high elevations. Given the difficult sampling conditions, limited sample sizes, and imperfect detection, our failure to detect specific pathogens should be interpreted with caution. Moreover, recent sampling efforts suggest that nasal swabs are more effective than are swabs of tonsillar crypts for detecting P. multocida, an important bacterial respiratory pathogen (Weiser et al. 2003; Wood et al. 2017), but were not included in our sampling methods. Nonetheless, our results indicate a resident pathogen community containing both M. ovipneumoniae and Pasteurellaceae within the northeast and southwest GYA. Although multiple Pasteurellaceae species were detected in GTNP, we did not detect M. ovipneumoniae in the 14 animals sampled. Not surprisingly, southeast Alaska had the fewest 


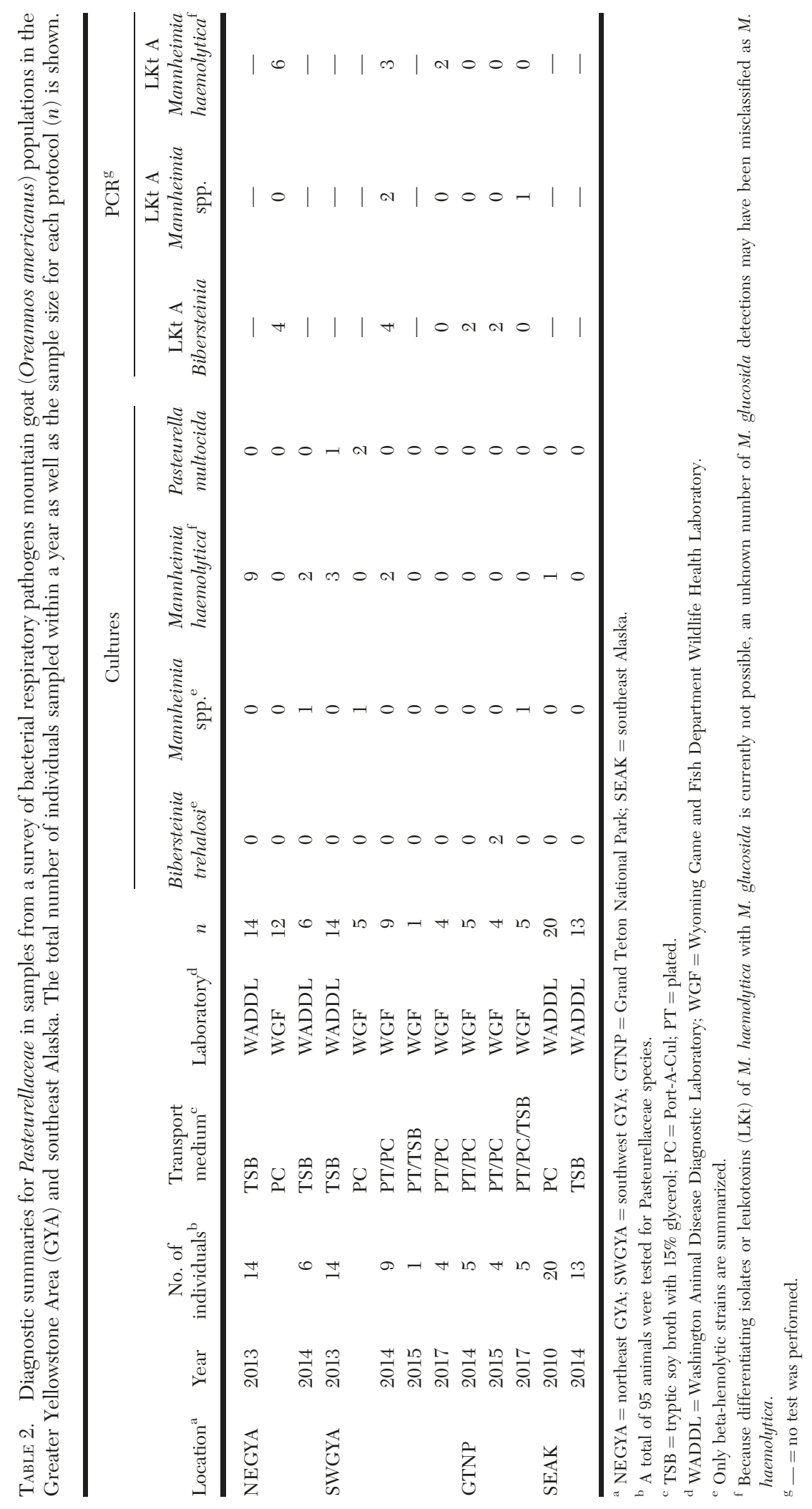


detections of Pasteurellaceae and no detections of M. ovipneumoniae.

Little is known about diseases in mountain goats; however, recent findings in Nevada highlight their susceptibility to respiratory disease (Wolff et al. 2014; Blanchong et al. 2018). With a number of mountain goats populations in decline regionally, respiratory disease may serve as an important yet previously underappreciated cause of mortality. Moreover, because of the strong niche overlap of bighorn sheep and mountain goats (Lowrey et al. 2018), characterizing the respective pathogen communities should be an important prerequisite to establishing new sympatric populations or understanding the potential for interspecific transmission on existing sympatric ranges (Wolff et al. 2016). These dynamics highlight the challenges associated with managing sympatric mountain ungulates and the importance of characterizing local pathogen communities to inform the management and conservation of both species.

We would like to thank the many agency biologists, wildlife veterinarians, regional game wardens, and other personnel who facilitated capturing and sampling efforts. Financial support was provided by Wyoming Game and Fish Department, Idaho Fish and Game, Alaska Department of Fish and Game, Canon USA, Inc. (via Yellowstone Forever), Wyoming Governor's Big Game License Coalition, National Park Service, and the Rocky Mountain Goat Foundation. Leading Edge (Clarkston, Washington, USA) conducted many of the animal captures.

\section{LITERATURE CITED}

Anderson CA, Blanchong JA, Nelson DD, Plummer PJ, McAdoo C, Cox M, Besser TE, Munoz-Gutierrez J, Wolff PL. 2016. Detection of M. ovipneumoniae in pneumonic mountain goat kids. Proceedings of the Nineteenth Biennial Symposium Northern Wild Sheep and Goat Council 20:80.

Besser TE, Cassirer FE, Highland MA, Wolff P, JusticeAllen A, Mansfield K, Davis MA, Foreyt W. 2013. Bighorn sheep pneumonia: Sorting out the cause of a polymicrobial disease. Prev Vet Med 108:85-93.

Blanchong JA, Anderson CA, Clark NJ, Klaver RW, Plummer PJ, Cox M, McAdoo C, Wolff PL. 2018.
Respiratory disease, behavior, and survival of mountain goat kids. J Wildl Manag 82:1243-1251.

Butler CJ, Edwards WH, Jennings-Gaines JE, Killion HJ, Wood ME, McWhirter DE, Paterson JT, Proffitt KM, Almberg ES, White PJ, et al. 2017. Assessing respiratory pathogen communities in bighorn sheep populations: Sampling realities, challenges, and improvements. PLoS One 12:e180689.

Cassirer EF, Manlove KR, Almberg ES, Kamath PL, Cox M, Wolff P, Roug A, Shannon J, Robinson R, Harris $\mathrm{RB}$, et al. 2018. Pneumonia in bighorn sheep: Risk and resilience. J Wildl Manag 81:32-45.

Côté SD, Festa-Bianchet M. 2003. Mountain goat. In: Wild mammals of North America: Biology, management, and conservation, Feldhamer GA, Thompson BC, Chapman JA, editors. Johns Hopkins University Press, Baltimore, Maryland, pp. 1061-1075.

Flesch EP, Garrott RA, White PJ, Brimeyer D, Courtemanch AB, Cunningham JA, Dewey SR, Fralick GL, Loveless K, McWhirter DE, et al. 2016. Range expansion and population growth of non-native mountain goats in the Greater Yellowstone Area: Challenges for management. Wildl Soc Bull 40:241250.

Lowrey B, Garrott RA, McWhirter DE, White PJ, DeCesare NJ, Stewart ST. 2018. Niche similarities among introduced and native mountain ungulates. Ecol Appl 28:1131-1142.

Lowrey B, Garrott RA, Miyasaki HM, Fralick G, Dewey SR. 2017. Seasonal resource selection by introduced mountain goats in the southwest Greater Yellowstone Area. Ecosphere 8:e01769.

Mountain Goat Management Team. 2010. Management plan for the mountain goat (Oreamnos americanus) in British Columbia. In: British Columbia Management Plan Series, Ministry of Environment, Victoria, British Columbia, Canada, pp. 1-87.

Rice CG, Gay D. 2010. Effects of mountain goat harvest on historic and contemporary populations. Northwest Nat 91:40-57.

Smith BL, DeCesare NJ. 2017. Status of Montana's mountain goats: A synthesis of management data (1960-2015) and field biologists' perspectives. Final report. Montana Fish, Wildlife, and Parks, Missoula, Montana, $51 \mathrm{pp}$.

Weiser GC, DeLong WJ, Paz JL, Shafii B, Price WJ, Ward ACS. 2003. Characterization of Pasteurella multocida associated with pneumonia in bighorn sheep. $J$ Wildl Dis 39:536-544.

Wolff P, Besser TE, Nelson DD, Ridpath J, McMullen K, Munoz-Gutierrez J, Cox M, Morris C, McAdoo C. 2014. Mountain goats at the livestock-wildlife interface: A susceptible species. Proceedings of the Nineteenth Biennial Symposium Northern Wild Sheep and Goat Council 19:13.

Wolff PL, Cox M, McAdoo C, Anderson CA. 2016. Disease transmission between sympatric mountain 
goats and bighorn sheep. Proceedings of the Nineteenth Biennial Symposium Northern Wild Sheep and Goat Council 20:79.

Wood ME, Fox KA, Jennings-Gaines JE, Killion HJ, Amundson S, Miller MW, Edwards WH. 2017. How respiratory pathogens contribute to lamb mortality in a poorly performing bighorn sheep (Ovis canadensis) herd. J Wildl Dis 53:126-130.

Submitted for publication 2 February 2018.

Accepted 18 April 2018. 